\title{
SMART GRIDS IN THE PROCESS OF BUILDING A COMPETITIVE ECONOMY AND ENERGY SECURITY IN EUROPE
}

\author{
Anna LUDYNIA \\ Faculty of Management \\ Warsaw University of Technology, Warsaw, Poland \\ e-mail: a.ludynia@interia.pl
}

\begin{abstract}
Article aims to present the technological innovation - Smart Grids in the process of maintaining Europ's energy security, competitiveness of economy and environmental protection. Innovative intelligent networks are the solution to accelerate the liberalization process of the energy sector, and also to grow energy efficiency and savings in the consumption of electricity. Management of energy production and efficient planning of consumption will bring benefits for the economic development. Technology of smart grids will change in the future the structure of the supply of energy towards a decentralization system. This article consist of three main parts, the first concerns the analysis of energy policy in Europe with the most significant factors that shape this policy, the seconde part concerns the presentation of the smart grids solutions essence for electricity and the benefits generated by the process of implementing in the energy system. The third part is devoted to European and Polish projects in the subject of smart meters.
\end{abstract}

Keywords: energy innovations, energy technologies, energy policy, competitive economy.

1

\section{Introduction}

Smart Grid in contemporary Europe and the world economy is an innovation and challenge, which allows people in the future to gain a stable position on energy, economic and environmental protection.

Due to the importance of this issue, I think that there is a great need to take this subject in a public forum, because in many countries there is the lack of knowledge on this topic, which also is confirmed on social evidence.

Innovative intelligent network in power industry and in the entire economy is now essential to energy safety, effective management of limited resources and it provides economic development of the country.

My primary purpose in this article is to justify the introduction of intelligent networks, together with the presentation of the essence of the smart grids action and also to present some of the projects on a European scale, in which Poland has some part or is an independent executor.

\section{Key factors affecting energy policy in Europe}

European energy policy, which is reflected by climate and energy package $20-20-20$ is to introduce in the
European Union so called "Green revolution" both in industry and energy, but in particular it has to lead to a move away from high emission coal for renewable energy and energy efficiency. The basic assumptions of the package proposed by the European Commission in January 2008 are:

- reduction in $\mathrm{CO} 2$ emission by $20 \%$ in 2020 in comparison with 1990 ,

- increased use of renewable energy in the EU from the present $8.5 \%$ to $20 \%$ in 2020 , for Poland the growth was adopted from 7 to $15 \%$,

- the increase of energy efficiency in 2020 by $20 \%$.

In particular way, it should be emphasized that the increase in energy efficiency has a significant impact on reducing $\mathrm{CO} 2$ emissions and also to increase renewable energy in the structure of energy production.

The reasons for this energy policy are rooted in the existing energy resources in Europe and the world, in the prices of fuels, the consumption of energy and environmental protection.

It is therefore important to provide some economic indicators that will allow the characterization of the current energy situation in Europe, as well as trends in the behavior of these quantities in the future. 


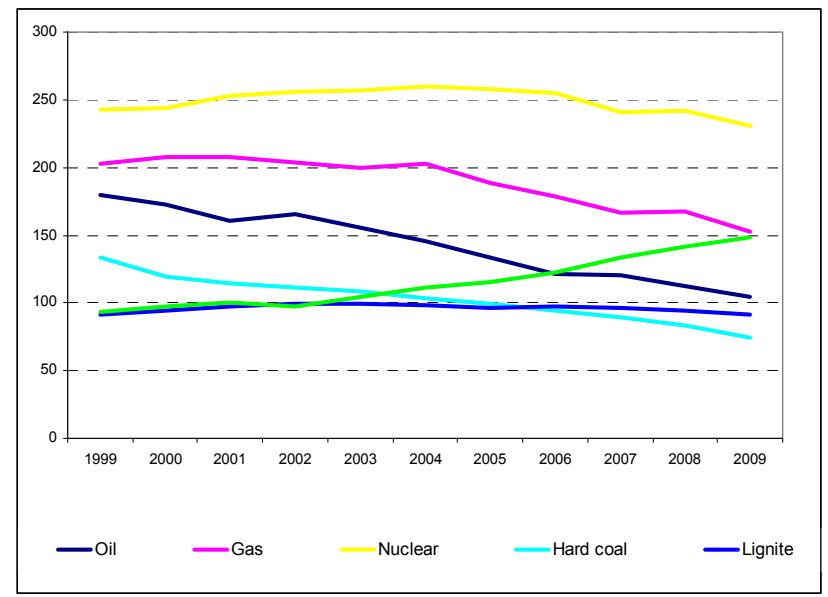

Figure 1. Production of primary energy sources in the years 1999 - 2009 (source: Energy, transport and environment indicators. Eurostat 2011)

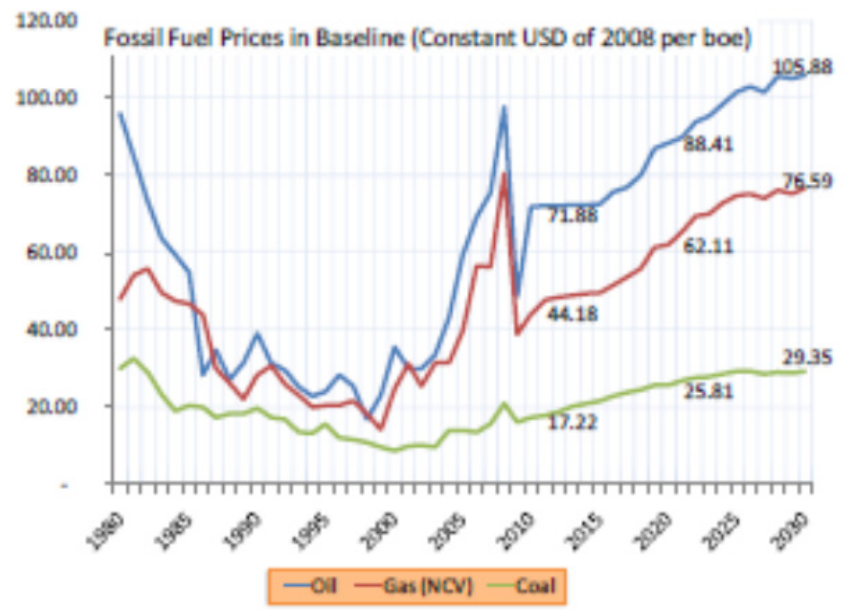

Figure 2. World fossil fuel prices

(source: EU Energy Trends to 2030 - update 2009, European Commission, 2010)

The Fig. 1 shows that the countries of the European Union in the period 1999-2009 recorded a downward trend (that is 14\%) in the extraction of primary energy sources, especially the fact existed between 2008 and 2009. Production of nuclear energy is the highest in the EU in relation to fossil fuels which is largely due to French and German energy potential. On the other hand, it is important phenomenon that a significant increase in the share of production from renewable energy sources (RES) has been in the last decade $60 \%$.

The dependence of Europe in the subject of energy is on the level of $53,9 \%$, which represents the largest share of petroleum imports (mainly from Russia and Norway), and it must be emphasized that there is great demand for this raw material in the economies of the EU. The important information is that the total energy consumption in the world has increased $37,3 \%$ since 1990 where the highest consumption exist in the U.S., EU and China. The U.S. and EU economies are mainly based on oil consumption, while China's economy on fossil fuels.

The prices of fossil fuels have increased significantly in the last decade, and they will grow steadily to 2030 . (see Fig. 2) It is worth emphasizing that the oil will have the highest price, and about 38\% lower price gas will have, and the lowest price is to be expected for carbon that is by $60 \%$ compared to the price of oil as shown in the graph (see Fig. 2).

Efficient use of produced energy has improved significantly in the processes of economic activity in the last decade (14\%) and is located in 2009 at 812 Mtoe (in 1999. level was - 949 Mtoe). 


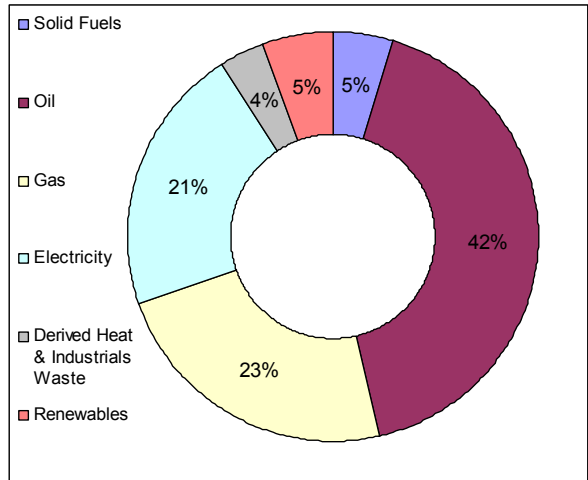

Figure 3. Final Energy Consumption - 27th EU (source: EU Energy and Transport in Figures, European Commission, Statistical Pocketbook, 2010)

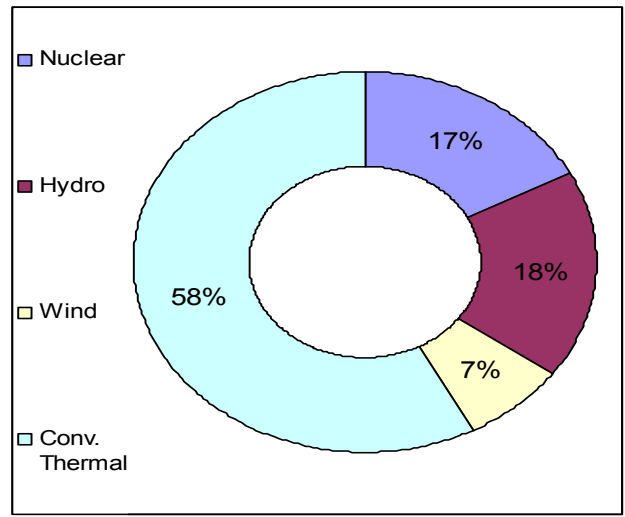

Figure 5. Electricity Production Capacity - EU-27 (in GW)

(source: EU Energy and Transport in Figures, European Commission, Statistical Pocketbook, 2010)

This phenomenon is a result of new, innovative technologies for better use of available energy sources.

These considerations lead to the finding that if the extraction of fossil fuels in Europe has decreased, and the economies of the European Union are based largely on the use of oil (and also gas in the second place), the basic conclusion is that in the near future, the EU economy significantly reduce their competitiveness in relation to the rest of the world, despite increasing energy efficiency.

However the further policies of energy dependence of the European Union will lead to increased economic risk, political and energy danger.

In addition, electrical power is a $21 \%$ share in the structure of the total energy consumption of European Union countries (see Fig. 3) and in Poland it is a level of 16\% (see Fig. 4).

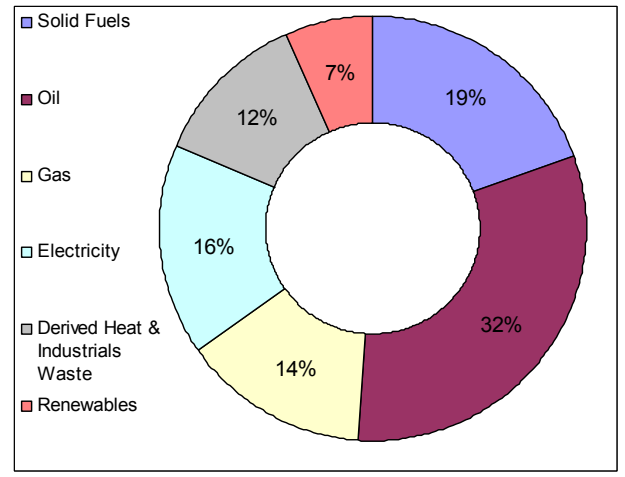

Figure 4. Final Energy Consumption - Poland (source: EU Energy and Transport in Figures, European Commission, Statistical Pocketbook, 2010)

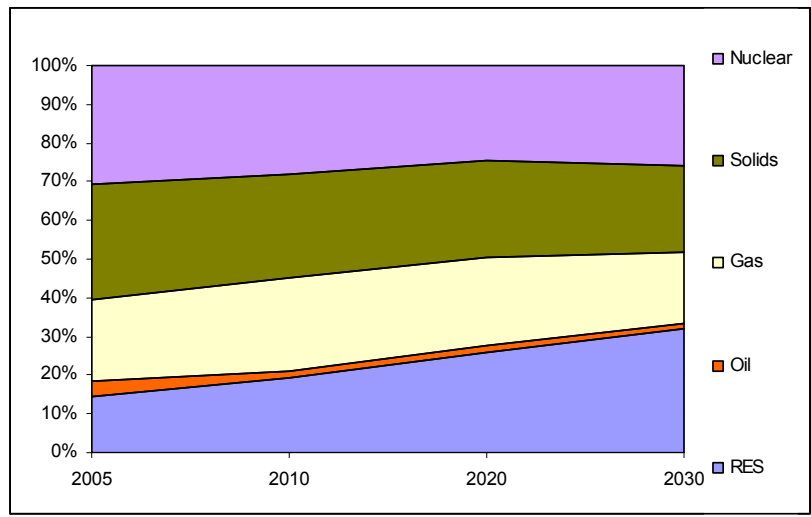

Figure 6. Gross Power Generation by Source by 2030 (source: EU Energy Trends to 2030 - update 2009, European Commission, 2010)

Electricity production in the EU comes mainly from conventional sources $-57,7 \%$ and nuclear power $17,1 \%$ remaining sources of RSE $-25,2 \%$.

Conventional energy resources (coal, oil, gas) for electricity production dominate at a high degree in Germany, Great Britain, France, Italy and Poland. Nuclear energy is essential for the production of electricity, in France and Germany particularly, renewable energy (hydro power) in Sweden, wind power and solar power in Spain and in Italy - mainly hydro power. In the years 1990 - 2007 in Europe, the production of wind energy was reported with the largest increase. Renewable energy sources in the structure of electricity generation in recent years are rising to a considerable extent. A similar trend is also projected to 2030 (see Fig. 6). In addition, there is a decrease share of gas by $5,2 \%$ compared to $2010,4,7 \%$ share of fossil fuels and $2,1 \%$ share of nuclear energy. 


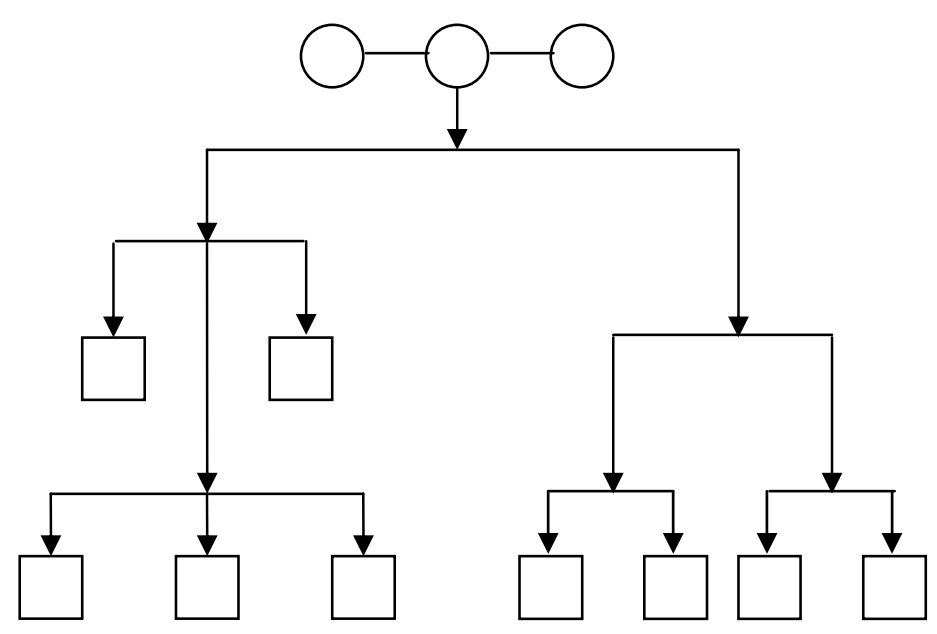

Figure 7. Diagram of the conventional power grids (source: own elaboration)

Conventional sources are projected to gradually decline (gas, coal and oil) in the production of electricity. This fact is due to the EU energy policy mainly, environmental and economic considerations and significant increase in the prices of these fuels as a result of changes in supply and a gradual decline in the rate of economic growth in Europe.

\section{Smart grid as the essence of innovative technology growth of the efficiency and competitiveness of the european economy}

In the energy policy of the European Union, electricity production sector holds an important place, because it has a growing role in the economy and affects the quality of life. One of the fundamental problems of economic development is to meet rapidly growing demands for electricity, whose production is more and more expensive and still harmful to the environment, and what is more the European Union countries are increasingly dependent on imported energy resources.

Therefore, it is necessary to expand production capacity, modernize aging energy infrastructure and transmission infrastructure while taking into account environmental protection. All these elements impact on the system's energy security.

The solution of these problems requires intensified actions that can be implemented in the traditional or innovative form. Classical solutions previously used in the construction of power units, and energy networks requires high capital and time. So essential is now a new way to support energy security, based on innovative technologies that allow more efficient use of energy resources, better management of them, and introduction of new forms of energy sources for electricity generation.

The implementation of these challenges requires a flexible network and "thinking" infrastructure that will provide energy exactly where there is demand, so called - smart grid.

\subsection{Nature and potential of innovation in the smart grid}

In the literature concerning smart grid it is difficult to find a clear definition of the term above. Therefore, to clarify the idea of such innovation will consist in presentation of the basic characteristics associated with its operation

Electrical energy has a growing importance in the European economy and the world. A characteristic feature of the modern world is the digitization of many economic sectors and spheres of society, which began with the creation of mobile Internet and fast communication and remote control.

Therefore, the existing electricity networks also require specific changes to adapt to the digital environment.

The current operation of power transmission systems is to use large power plants in the hierarchical, one-way system, that is from the generator of electricity through transmission and distribution network to the final customer (see Fig. 7). The main weakness of the structure is too long way transmission of electricity to the enduser which causes numerous threats on route of transportation. 


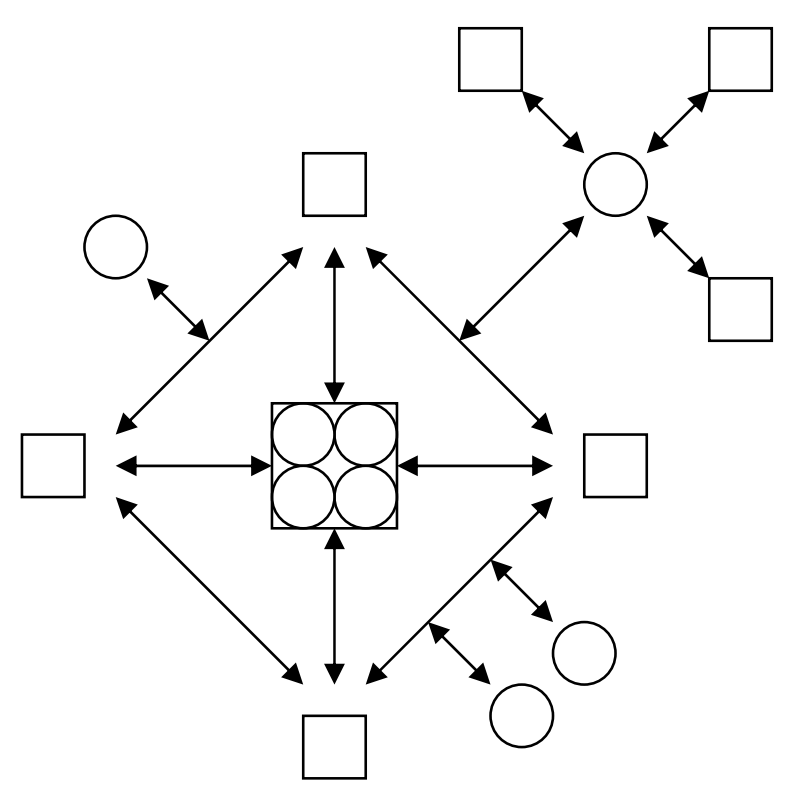

Figure 8. Diagram of smart energy networks - Smart Grids (source: own elaboration)

In addition, instability in the power supply throw lack of continuity of the quality parameters cause currently great economic damage in the production processes of enterprises.

Modern digital economy requires a smart grid that will comply with the following features (according to the U.S. Department of Energy agreed in June 2009):

- optimising the use of energy resources, and operational efficiency,

- use of all technology solutions for energy generation and storage,

- assurance of quality supply for all needs of the digital economy,

- prediction of disturbance in the system and respond to self-repair mode,

- having resistance to physical and cyber attacks and natural disasters,

- enabling active participation of customers,

- enabling the introduction of new products, services and markets ${ }^{1}$.

For these functions system must have a network structure with two-way communication where you can make the implementation of innovative technologies to increase economic efficiency and technical support (see Fig. 8).
Smart Grid is not an end in itself but a response to technical and economic level, against the challenges that the power sector is confronting in Europe and worldwide.

This Table 1 presents the main characteristics of intelligent energy networks which will be the future of the whole energy system of the world and Europe. An important difference compared to the previous hierarchical grids is that they are digitally controlled and have a network architecture which enables interaction between customers and the market.

The plans of introducing this kind of the power system will also bring many benefits to a number of entities operating in the energy industry. The Operators will have improved ability to monitor and control network, which will enable them to provide a higher level of system reliability. Distribution companies will have lower distribution losses, delay capital expenditures and reduced maintenance costs. Recipients will gain a greater impact on energy costs, including the possibility of self-power generation, while the benefits of more reliable energy supply. Moreover, the environment will benefit by reducing peak demand, the spread of renewable energy sources and related reduction in $\mathrm{CO} 2$ emissions and other pollutants.

\footnotetext{
${ }^{1}$ Feliachi A., Saymansky J., Choudhry M., Sneckenberger J. Are All Smart Grids Equal? Journal of Electrical Systems, 2011.
} 
Table 1. Comparative characteristics of the traditional electric power system with the Smart Grid network (source: Malko J. - Why do the networks have to be smart?, Wulkan, 1(18) 2011)

\begin{tabular}{|l|l|l|}
\hline & \multicolumn{1}{|c|}{$\begin{array}{c}\text { Hierarchical Network } \\
\text { (Traditional) }\end{array}$} & digital \\
\hline Steering, control, metering & electromechanical & bidirectional \\
\hline Communication, information flow & one-way & distributed \\
\hline Generation & centralized & network \\
\hline Architecture & hierarchical & universal \\
\hline Sensors & a few & own monitoring \\
\hline Transparency structure & untransparent & self-correcting \\
\hline $\begin{array}{l}\text { Disaster recovery activities, failures, } \\
\text { black-outs }\end{array}$ & manually corrected & remote \\
\hline Inspection / Testing & manual & all-encompassing \\
\hline Communication with customer & limited & many choices \\
\hline Chance of selection by the user & low & \multicolumn{1}{|c|}{. } \\
\hline
\end{tabular}

According to the U.S. research institute EPRI (Electric Power Research Institute), the investment in the development of smart grid technologies and their implementation in the U.S. in the amount of 165 billion. \$ bring revenues from 638 to 802 billion dollars. This means the factor income / expense in the amount of from $4: 1$ to $5: 1^{2}$.

\subsection{The conditions, which necessitate introduction of intelligent energy}

\subsubsection{Climate change}

In the years 2004-2010 there were in Poland and Europe (Sweden, Germany, Italy), a number of catastrophic events that led to the widespread network failure (blackouts), and whose causes were severe weather anomalies. As a result of increasing tensions and despite an avalanche of efficient sources of power, many customers were devoid of power for several days which in turn led to significant economic losses. Moreover, the process of restoring power supply was a complicated and time consuming.

These facts confirm that the historical structure of energy systems is no longer suitable to the task

\footnotetext{
${ }^{2}$ Sedler B. - Smart electricity networks - as condition for the development of green energy. Scientific and Technical Foundation, Gdańsk 2011.
}

of increasing economic requirements and climate change. Particular importance is the lack of information between transmission systems about the actual state of each device.

\subsubsection{Lack of exploit the potential which functions in the systems of decentralized sources}

Global energy demand is increasing rapidly due to economic development, growth service level and quality of life. It is estimated that the growth rate is approximately 2,2\% per year. Aging energy infrastructure, both in Poland and Europe needs to modernize and maximize the efficiency of energy flow.

Those conditions require intensified activity to increase production capacity of electricity. It is therefore essential that the different sources of electricity generation had its share in meeting the needs of customers, that is to varying degrees and at different levels.

There is a huge demand for power grid to enable connection of distributed generation sources of renewable energy especially, those that are less harmful for the environment. 


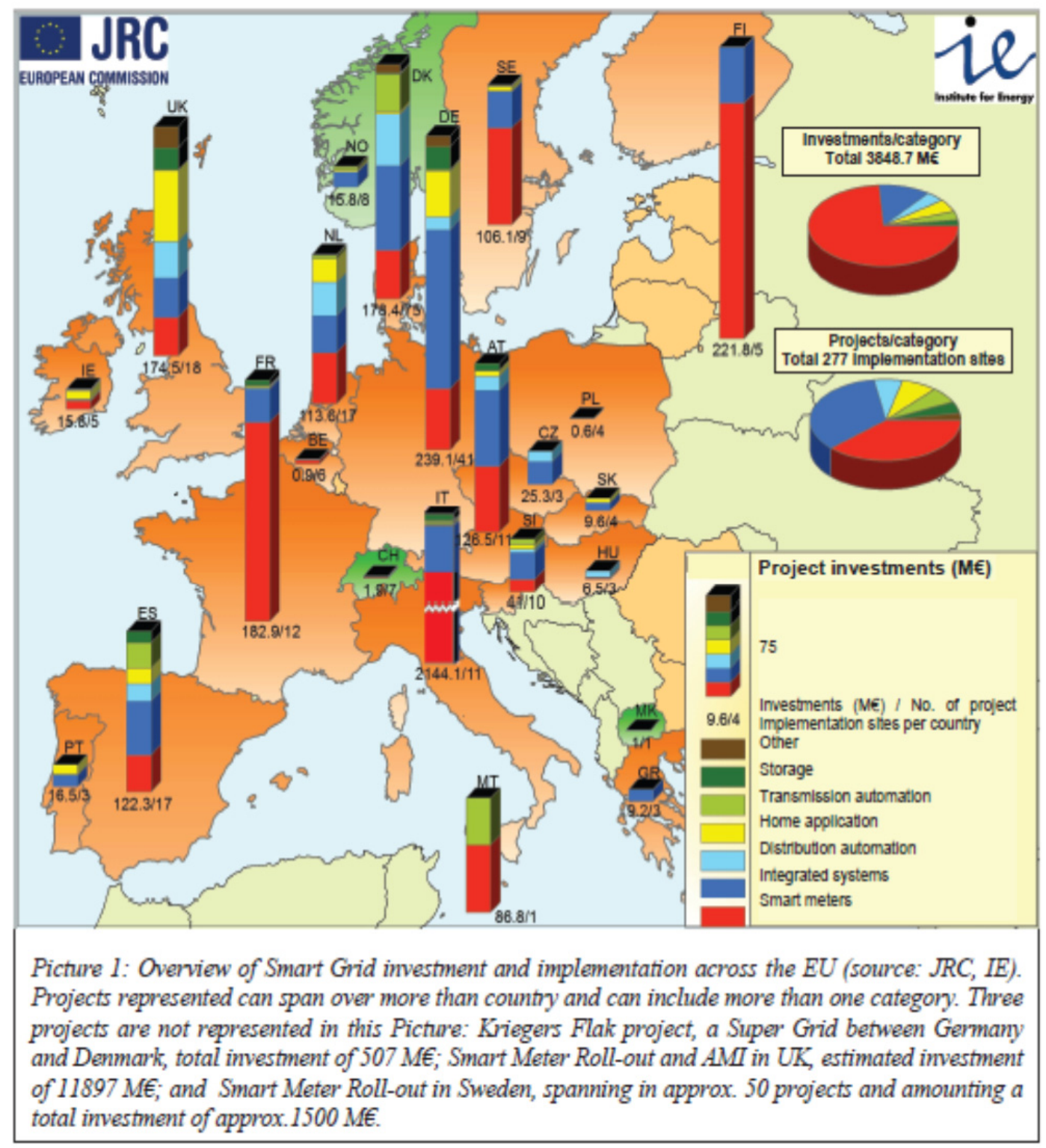

Figure 9. Overview of Smart Grid Investments and Implementation across the EU

(source: European Commission, "Communication from the Commission to the European Parliament, The Council, The European Economic and Social Committee and the Committee of the Regions. Smart Grids: from innovation to deployment")

\subsubsection{The existing power system does not allow for the proper implementation of the new ecological findings in the European Union}

The advent of electric vehicles in use is a form of energy storage but also they will require an increased demand for energy. Consistent development of distributed energy storage technologies and related new products and services bring the demand for new smart energy system.

\subsubsection{Intelligent Energy will introduce the benefits from the prosumption}

It is important for the raise of production capacity and the country's energy security to provide for many customers the possibility to generate and sell power to the system which will allow for more efficient use of available primary and secondary sources in each region. Without the implementation of the Smart Grid the benefits from the prosumption task will not be possible. 


\subsubsection{Increasing efficiency of the primary and secondary energy}

The current energy system does not allow for ongoing monitoring and effective management of electrical energy use and energy recovery which can be used mainly on a local scale

Moreover, thanks to the smart grid will reduce the cost of disaster recovery and the associated loss of produced energy ${ }^{3}$.

\section{Details of the implementation of the smart grid in the energy system in Europe and the world}

The functioning smart grid in the advanced stage which will work effectively and meet the needs of today's digital economy requires implementation of the following elements:

- smart meters and related advanced structures - AMI,

- automatic transmission and distribution networks,

- applications including the integration of the whole energy system,

- software applications tailored to customer behawior,

- energy storage.

Each of these constituent elements is implemented to varying degrees in national and international projects of the European Union countries.

According to the data contained in the Commission Communication to the European Parliament (dated 12 April 2011), it was estimated that in EU countries was invested in the last decade, more than $€ 5,5$ billion in about 300 projects to implement smart grid. As a comparison, the U.S. has invested $\$ 8,1$ billion and in China $\$ 7,3$ billion ${ }^{4}$.

The European Union is still in early stages of implementing smart grid especially if one takes into account that for 2020. is planned to invest in this venture $€ 56$ billion.

\footnotetext{
3 Kowalak T. - The implications of smart grid Technologies (smart meters) - smart meters and smart grids - for the security of electricity supply. Monographs Technical University of Lodz, 2011.

${ }^{4}$ European Commission - Communication from the Commission to the European Parliament, The Council, The European Economic and Social Committee and the Committee of the Regions. Smart Grids: from innovation to deployment. Brussels, 12.4.2011
}

As it follows from the figure above, a leader in investment projects regarding smart meters, are Italy with national Telegestore project where the system is mainly based more on reduction non-technical loss than the same energy savings (see Fig. 9).

Significant values of smartmetering investment in $\mathrm{Eu}-$ rope include France, Sweden and Finland.

High investment in smart meters have a large stake in the structure of the Smart Grid projects in many European countries because of the expectations for the following issues:

- reducing the cost of theft of energy,

- possibility of remote activation and deactivation of services,

- rapid detection of energy flow on the network,

- a better management of difficult customers (bad payers).

In the future these investments will be the basis of additional benefits derived from the consumer supply, in so-called the dynamics of pricing preview, which depends on the future functionality of the system, the attached application, connection of intelligent devices.

Previously installed smart meters allow consumers to reduce energy consumption to $10 \%$ (according to the project Telegestore, Italy). By contrast, many European projects, point to a much greater impact on $\mathrm{CO} 2$ emissions reduction, that is from $9 \%$ to $15 \%$.

It is also important and interesting that the implementation of smart metering in modern economies will also allow the development of intelligent devices for the consumer. It is expected that the market for this kind of goods will grow globally from \$3,06 billion. in 2011 to $\$ 15,12$ billion. (Tab 2) in 2015. where most of its shares will take place in the U.S. $(46,6 \%)$, China $(11,6 \%)$, UK (4,8\%), Austria (2,8\%), and the rest of the world $34,2 \% 5$.

An important part of the process of implementing smart grid to the full extent in the European system are the following:

- safe integration of distributed energy resources (DER) (distributed generation, storage, electric cars),

- possible response of the consumer to price (DR),

- security integration of renewable sources (RES).

\footnotetext{
${ }^{5}$ Zpryme Research \& Consulting - Smart Grid Insights: Smart Appliances, March 2010.
} 
Table 2. The estimated global market for smart devices according to individual products in 2015. (billion \$) (source: Zpryme Research \& Consulting - Insights Smart Grid: Smart Appliances, March 2010)

\begin{tabular}{|c|c|}
\hline Washing Machines & $\$ 3,542$ \\
\hline Refrigerators & $\$ 2,693$ \\
\hline Dryers & $\$ 2,236$ \\
\hline Dishwashers & $\$ 1,354$ \\
\hline Freezers & $\$ 1,166$ \\
\hline
\end{tabular}

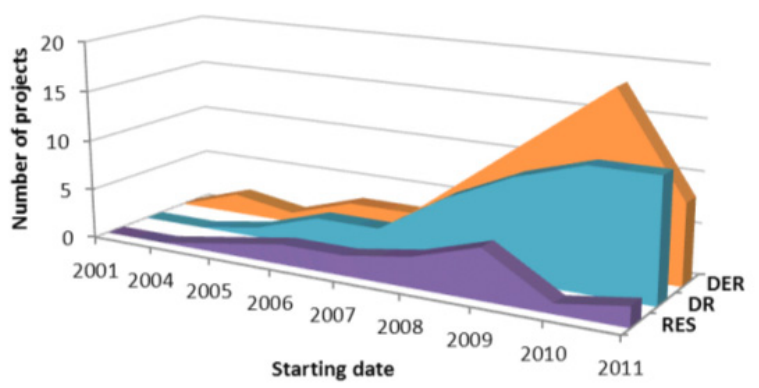

Figure 10. Trend of development projects focusing on intelligent network elements such as RES, DER, DR in the years 2001-2011

(source: European Commission, Institute for Energy - Smart Grid Projects In Europe: lessons learned and current developments, 2011)

Table 3. The structure of the various phases of projects to implement smart grid in Europe (source: European Commission, Institute for Energy, "Smart Grid Projects In Europe: lessons learned and current developments, 2011)

\begin{tabular}{|c|c|c|c|}
\hline Projects & R\&D & $\begin{array}{c}\text { Demonstration } \\
\text { projects }\end{array}$ & Deployment \\
\hline DR & $29 \%$ & $71 \%$ & $0 \%$ \\
\hline DER & $33 \%$ & $67 \%$ & $0 \%$ \\
\hline RES & $56 \%$ & $44 \%$ & $0 \%$ \\
\hline $\begin{array}{c}\text { Smart } \\
\text { Meters }\end{array}$ & $8 \%$ & $60 \%$ & $32 \%$ \\
\hline
\end{tabular}

Projects which are focusing on the integration of distributed energy resources, there is the DER and DR, are in a continuous upward trend (see Fig. 10) and most of them are mainly in their R\&D and demonstration projects (Table 3). The development of these phases of the project are the result of an advanced implementation of smart meters.
DR projects are increasingly transformed into a phase of demonstration projects to increase the degree of involvement of consumers and gain their trust which is an essential element in the operation of smart grids. The benefits of energy savings on part of the consumers are at the level of 10-15\% (eg. GAD Project). 


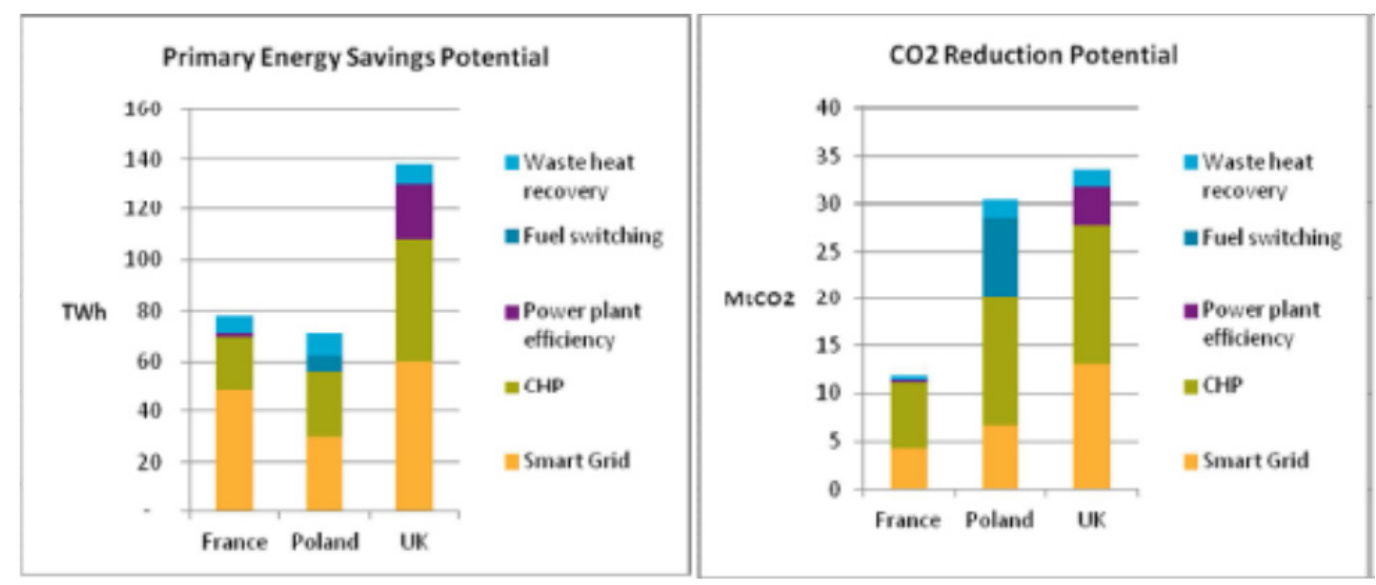

Figure 11. The structure of techniques for saving primary energy and reduce $\mathrm{CO} 2$ emissions in France, Poland and Great Britain.

(source: Brown M., McLeavey-Reville C. - Driving a resource efficiency Power Generation Sector in Europe, Delta Energy \& Environment, May 2011)

Projects on smart meters are in a more mature phase, as evidenced by the $30 \%$ of them was located in the deployment phase, while only $8 \%$ of these projects is still in R \& D (eg. OpenNode Project, OpenMeter Project, SyM2 Project).

All the projects as DSO (Distribution System Operator) which includes the Advanced Metering Infrastructure (AMI), the integration of DER and Demand Responce are based on smart meter systems and are aimed at saving energy theft in the field of logistics and operations, customer service and focused on the reduction of operating costs.

\subsection{The outline of implementation projects in an intelligent polish network}

The increasing Polish position in international organizations, the accession to the European Union forced Poland to participate in several obligations, which generally serve two objectives: climate protection and the full implementation of the principle of free movement of goods - one of the pillars of a United Europe.

In a view of the above-identified Polish international obligations in the field of climate protection as well as the need for more the energy markets competitiveness, the Polish energy sector is in a particular position.

The structure of the Polish electricity generation continues to dominate the emitting fuels, and there is inad- equate and outdated transmission and distribution infrastructure. The economic growth imposes an increased demand for energy in the future and will lead to a deficit of power in the system and, consequently, the power cuts.

Due to the above considerations taken by Poland the smart grid initiatives, therefore, seems to be obvious. But so far, Poland is at the beginning of the implementation process, there is at $1,7 \%$ of expenditures in comparison to other European Union countries.

Because of the national energy balance analysis, implementation of smart grid is probably a necessity, but not replace, however, of investments in new generation capacity and transmission infrastructure, which so far are insufficient and also from year to year decline.

In general, energy savings can result from the possibility of using such methods and techniques such as:

- the introduction of the cogeneration process,

- increase the efficiency of power plants,

- fuel switching, recovery of waste heat and also through,

- smart grid.

Each of these methods has a significant impact on primary energy savings but also the potential for reducing CO2 emissions (see Fig. 11). 
Table 4. Polish projects in the process of implementing smart grid in power networks (source: European Commission, Institute for Energy - Smart Grid Projects In Europe: lessons learned and current developments, 2011)

\begin{tabular}{|c|c|c|c|c|}
\hline Name of project & Organisation & $\begin{array}{l}\text { Co- } \\
\text { untry }\end{array}$ & Description of project & Period \\
\hline AMI & $\begin{array}{l}\text { ENERGA- } \\
\text { OPERATOR } \\
\text { SA (PL) }\end{array}$ & PL & $\begin{array}{l}\text { The project is focused on Increasing the effectiveness } \\
\text { of operational activity and facilitating management of } \\
\text { the network and its development; Remote management } \\
\text { of meter systems and obtaining meter data; Activation } \\
\text { of clients in energy effectiveness and dispersed genera- } \\
\text { tion; }\end{array}$ & $2010-2017$ \\
\hline $\begin{array}{l}\text { Introduction } \\
\text { of emergency } \\
\text { Demand Side } \\
\text { Response (DSR) } \\
\text { programs }\end{array}$ & $\begin{array}{l}\text { PSE } \\
\text { Operator } \\
\text { S.A.(PL) }\end{array}$ & PL & $\begin{array}{l}\text { The main goal of the pilot project is to gain practical } \\
\text { experience of the functioning of emergency DSR pro- } \\
\text { grams in Smart Grid/smart Meters environment. This } \\
\text { experience will be used to develop the target DSR } \\
\text { programs. }\end{array}$ & 2011-2012 \\
\hline $\begin{array}{l}\text { The metering data } \\
\text { processing and } \\
\text { central repository } \\
\text { concept }\end{array}$ & $\begin{array}{l}\text { PSE } \\
\text { Operator } \\
\text { S.A.(PL) }\end{array}$ & PL & $\begin{array}{l}\text { The goal of the project is to prepare cost benefit analy- } \\
\text { sis of smart metering implementation in Poland and to } \\
\text { develop the legal and organizational framework to } \\
\text { implement metering data processing and central reposi- } \\
\text { tory concept. }\end{array}$ & 2010-2011 \\
\hline
\end{tabular}

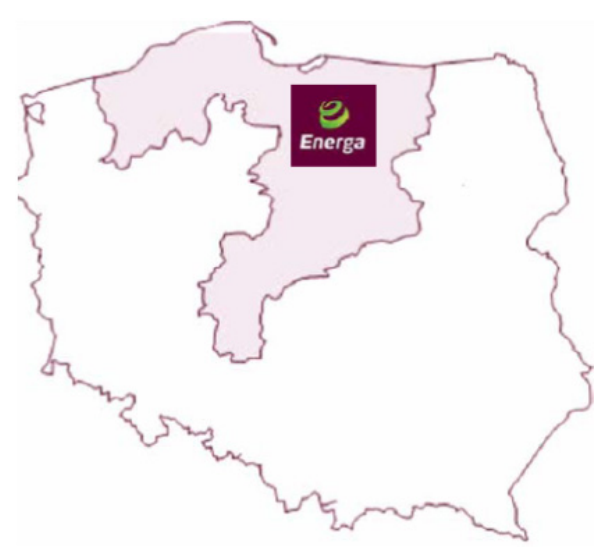

Figure 12 The largest planned project AMI in Poland conducted by AMI-Energa Operator. (source: Energa-Operator SA)

The following graphics show the importance of Smart Grid in the process of primary energy savings and reduce carbon emissions. Although the initial phase of the Smart Grid, Poland has already initiated three major projects carried out by the largest operators of transmission (Table 4). There are AMI, introduction of emergency Demand Side Response and the Metering data processing and central repository concept.

They are designed to introduce smart meters and associated high-energy infrastructure (AMI project conducted by Energa), and create a basis for integrating the entire system in the construction of the future smart grid - projects conducted by PSE Operator (details of polish projects are included in Table 4).

The first and biggest project in Poland concerning the introduction of smart metering solutions for largescale is run by Energa Operator SA, a distributor of energy from the Group of Energia (see Fig. 12). This project is called "Implementation of AMI (Advanced Metering Infrastructure - smart metering)." 
Table 5. Summary and description of some international projects for intelligent energy networks, in which Poland is a member

(source: European Commission, Institute for Energy, Smart Grid Projects In Europe: lessons learned and current developments, 2011)

\begin{tabular}{|c|c|c|c|c|}
\hline Name of project & $\begin{array}{l}\text { Entity } \\
\text { conduc- } \\
\text { ting the } \\
\text { project }\end{array}$ & $\begin{array}{l}\text { Coun- } \\
\text { tries }\end{array}$ & Description & Period \\
\hline EU-DEEP & $\begin{array}{l}\text { GDF Suez } \\
\text { (FR) }\end{array}$ & $\begin{array}{l}\text { FR, EL, } \\
\text { UK, DE, } \\
\text { BE, ES, } \\
\text { SE, PL, } \\
\text { LV, AT } \\
\text { HU, IT, } \\
\text { FI, CY, } \\
\text { CZ, TR }\end{array}$ & $\begin{array}{l}\text { The project brings together eight European energy utilities } \\
\text { and aims at removing most of the technical and non-technical } \\
\text { barriers that prevent a massive deployment of distributed energy } \\
\text { resources (DER) in Europe. In partnership with manufacturers, } \\
\text { research organizations, professionals, national agencies } \\
\text { and a bank, they implemented a demand-pull rather than technol- } \\
\text { ogy-push approach. This new approach provided three tentative } \\
\text { "fast-tracks options" to speed up the large-scale implementation } \\
\text { of DER in Europe, by defining three client portfolios in various } \\
\text { market segments which could benefit from DER solutions, and by } \\
\text { fostering the R\&D required to adapt DER technologies to the } \\
\text { demands of these segments. }\end{array}$ & $\begin{array}{l}2004- \\
2009\end{array}$ \\
\hline $\begin{array}{l}\text { EWIS - European } \\
\text { wind integration } \\
\text { study }\end{array}$ & $\begin{array}{l}\text { ELIA } \\
\text { SYSTEM } \\
\text { OPERA- } \\
\text { TOR SA } \\
\text { (BE) }\end{array}$ & $\begin{array}{c}\text { BE, AT, } \\
\text { DE, FR, } \\
\text { PT, ES, } \\
\text { PL, UK, } \\
\text { EL, IE, } \\
\text { DK, CZ, } \\
\quad \text { NL }\end{array}$ & $\begin{array}{l}\text { The project aims to work with all the relevant stakeholders espe- } \\
\text { cially representatives of wind generation developers. The study } \\
\text { will use results from detailed network and market models of the } \\
\text { European transmission system for scenarios representing immedi- } \\
\text { ate and longer-term needs. } \\
\text { The recommendations will be aimed at developing, where possi- } \\
\text { ble and appropriate, common European solutions to wind integra- } \\
\text { tion challenges }\end{array}$ & $\begin{array}{l}2007- \\
2009\end{array}$ \\
\hline $\begin{array}{l}\text { Micro-Request- } \\
\text { Based Aggrega- } \\
\text { tion Forecasting } \\
\text { and Scheduling } \\
\text { of Energy } \\
\text { Demand, Supply } \\
\text { and Distribution } \\
\text { (MIRABLE) }\end{array}$ & $\begin{array}{l}\text { SAP AG } \\
(\mathrm{DE})\end{array}$ & $\begin{array}{l}\text { EL, DE, } \\
\text { PT, NL, } \\
\text { DK, CH, } \\
\text { IT, ES, } \\
\text { FR, PL, } \\
\text { MK, UK }\end{array}$ & $\begin{array}{l}\text { The project's main goal is to develop a concept for flex-offers that } \\
\text { specify electricity demand and supply which is flexible in time } \\
\text { and amount and an infrastructural approach to process lots } \\
\text { of these flex-offers issued by small consumers and producers } \\
\text { in near real-time. } \\
\text { The possibility to shift demand within the mass of households } \\
\text { developed within the MIRACLE project will allow for a higher } \\
\text { share of fluctuating renewable energy sources in the energy mix } \\
\text { on the grid and reduce the peak demand. We expect that the share } \\
\text { of RES can be increased by } 5 \% \text { and that the peak demand can be } \\
\text { reduced by } 8-9 \% \text { (but at least by } 5 \% \text { ) for the total grid. } \\
\text { We will furthermore reduce the mean time between transactions, } \\
\text { which will result in more stability of the energy grid but also } \\
\text { in reduction of costs of BRPs, by reducing the difference between } \\
\text { their planned and actual electricity schedules. }\end{array}$ & $\begin{array}{l}2010- \\
2013\end{array}$ \\
\hline SUSPLAN & $\begin{array}{l}\text { SINTEF } \\
\text { ENERGI- } \\
\text { GI- } \\
\text { FORSKNI } \\
\text { NG A/S } \\
\text { (NO) }\end{array}$ & $\begin{array}{l}\text { PL, RO, } \\
\text { DE, AT, } \\
\text { UK, NL, } \\
\text { ES, BG, } \\
\text { CZ, IT, } \\
\quad \text { RS }\end{array}$ & $\begin{array}{l}\text { The overall impact from SUSPLAN is contribution to a substan- } \\
\text { tially increased share of renewable energy sources (RES) in Eu- } \\
\text { rope at an acceptable level of cost, thereby increasing security } \\
\text { of supply and competitiveness of RES industry. The main objec- } \\
\text { tive is to develop guidelines for more efficient integration of RES } \\
\text { into future infrastructures as a support for decision makers } \\
\text { at regional as well as Pan-European level. The guidelines shall } \\
\text { consist of strategies, recommendations, criteria and benchmarks } \\
\text { for political, infrastructure and network decision makers and } \\
\text { power distributors with a time perspective 2030-2050. }\end{array}$ & $\begin{array}{l}2008- \\
2011\end{array}$ \\
\hline web2energy & $\begin{array}{l}\text { HSE AG } \\
\text { (DE) }\end{array}$ & $\begin{array}{l}\mathrm{DE}, \mathrm{NL}, \\
\mathrm{AT}, \mathrm{PL}, \\
\quad \mathrm{CH}\end{array}$ & $\begin{array}{l}\text { The project Web2Energy is directed to implement and approve all } \\
\text { three pillars of "Smart Distribution". Smart Metering - the con- } \\
\text { sumer participates in the energy market Smart Energy Manage- } \\
\text { ment - Clustering of small power producers. Smart Distribution } \\
\text { Automation - higher reliability of supply. }\end{array}$ & $\begin{array}{l}2010- \\
2012\end{array}$ \\
\hline
\end{tabular}


Representatives of the operator Energa maintain that smart meters are the basis for intelligent network which is confirmed by the trend in the construction of pan-European smart grid.

In addition to the end of the first quarter of 2012, the company plans to install 100.000 smart meters in such regions like Kalisz, Drawsko Pomorskie and Hel in Poland.

Hel additionally has been selected by Energa as the location of Poland's first smart grid pilot project. In this place is also tested the possibility of the distributed generation (that is energy production in small sources, such as domestic solar panels, or agricultural biogas plants).

Energa assumes that all devices installed will become part of the infrastructure planned for the future grid.

To 2017 above energy company plans to replace the measuring devices in all of its customers, which is almost 3 million. Total project cost is estimated at over 1 billion zł.

The industry's largest companys like PSE Operator SA and also by Tauron Katowice, Vattenfall and Enea prepare pilot projects on a smaller scale than Energa. The aim of these projects is to assess the effectiveness and costs of the introduction and use of available technologies.

In addition to smart grids projects that are implemented by the major network operators in Poland, there are also international projects where Poland is actively cooperate. There are the following projects: EU-DEEP, EWIS, MIRABLE, SUSPLAN, Web2energy. These projects are mainly aimed at accelerating the introduction of a wide range of DER investment in Europe, identification of customer requirements and their segmentation (EU-DEEP, MIRABLE), the introduction of intelligent energy distribution (Web2energy), the increase share of renewable energy sources (Mirable, Susplan) and especially wind power (EWIS) - detailed description of international projects with the participation of Poland - Table 5)

\subsection{Social background of inteligent network introduction}

Despite many projects that are implemented throughout the world, in European countries, and also in Poland there is important a public knowledge in the topic of smart grids as a condition for the success of all plans in the sphere of increasing the efficient use of existing potential energy and climate protection.

The results presented in the "2011 IBM Global Utility Consumer Survey" showed, that many consumers in the world do not understand what makes up the price of energy and do not see the benefits of the new technologies.

IBM social study, which aimed to investigate the needs of energy consumers around the world, covered 10 thousand. people in 15 countries around the world, including Poland. It showed what kind of knowledge the energy consumers need to reduce power consumption and benefit from the intelligent energy. More than 60 percent people do not know the meaning of terms such as smart grids and smart meters.

Similarly, in Poland, where smart grids is almost unknown. As many as 76 percent. Polish respondents did not know what are the intelligent networks, and knowledge of the term "smart meter" is significantly below the global average. Polish people declare that they know very well for what they are paying. - 61 percent of respondents, while 54 percent Polish respondents do not realize that their energy supplier offers green energy or not.

The study also showed a close relationship between users knowledge, the expectation of change and acceptance of new energy initiatives. 61 percent. respondents possessing an established knowledge of energy and its prices have positive view of plans to create smart grids and smart meters. Among people with little knowledge on this subject, only 43 percent people welcome these plans.

We noted significant progress in the field of new energy saving technology. Meanwhile, many consumers do not understand the offers sent to them and the benefits that come from them. This study indicates the need for education with clear terms and using appropriate communication channels. People want to save, you need just to show them how to do it. The perception, expectation and performance of energy consumers have changed over the last 4 years. Despite the efforts of power engineers and the entire industry to create a friendly power saving utility customers, many of them still have no information or motivation to make better choices of energy. 


\section{$5 \quad$ Summary}

This paper is the result of statistical, economic analyzes and studies of literature in the field of innovative technologies in the supply of electricity and the efficiency of its utilization in the economy.

Smart energy networks are an innovation that among the various technologies holds an important place in the process of saving energy and reducing $\mathrm{CO} 2$ emissions. Moreover, the idea of the system architecture and operation of such grids allows for supporting of energy security and it is more suited to the action and the needs of modern digital economy.

Consequently, a number of projects in Europe but also in Poland put smart grids into economic reality.

So far, Europe's capital expenditures were focused on the implementation of smart meters with advanced structure of the AMI which, according to the results of the project in Italy Telegestore makes energy savings of $10 \%$ and also has an impact on reducing carbon emissions by $9 \%$ to $15 \%$. Additionally important is the fact that Smart Metering will also affect the development of intelligent devices that will not only support saving energy but also contribute to economic growth.

In the process of implementation of smart grids in the full range there are also important investment in technologies for the integration of distributed energy resources, the integration of renewable energy sources and technologies Demande Responce enabling the customer to actively participate in energy systems.

All of these technologies that will lead to the creation of smart grids in Europe will promote energy security and increase the energy efficiency and the impact on economic growth. However, despite the above considerations there should also be noted that the success of the project is also dependent on the awareness and the knowledge of each participant's energy system, which will allow to increase the economic benefits and social objectives with particular reference to the climate and the environment.

\section{$6 \quad$ References}

[1] Brown M., McLeavey-Reville C. - Driving a Resource Efficiency Power Generation Sector in Europe. Delta Energy \& Environment, May 2011.

[2] European Commission - Communication From the Commission to the European Parliament, the Council, the European Economic and Social Committee and the Committee of the Regions. Smart Grids: From Innovation to Deployment. Brussels, 12.4.2011.

[3] European Commission - EU Energy and Transport in Figures. Statistical Pocketbook 2010.

[4] European Commission - Smart Grid Projects In Europe: Lessons Learned and Current Developments. Institute for Energy 2011.

[5] European Commission 2010 - EU Energy Trends to 2030 - update 2009.

[6] Eurostat 2011 - Energy, Transport and Environment Indicators.

[7] Feliachi A., Saymansky J., Choudhry M., Sneckenberger J. - Are All Smart Grids Equal? Journal of Electrical Systems, 2011.

[8] Kowalak T. - The Implications of Smart Grid Technologies (Smart Meters) - Smart Meters and Smart Grids - for the Security of Electricity Supply. Monographs Technical University of Lodz 2011.

[9] Malko J. - Why Do the Networks Have to Be Smart? Wulkan, 1(18) 2011.

[10] Sedler B. - Smart Electricity Networks - as Condition for the Development of Green Energy. Scientific and Technical Foundation, Gdańsk.

[11] Zpryme Research \& Consulting - Smart Grid Insights: Smart Appliances. March 2010. 